\title{
KARAKTERISTIK POPULASI IKAN DI DANAU TONDANO, SULAWESI UTARA
}

\author{
Endi Setiadi Kartamihardja", Hendra Satria" dan Achmad S. Sarnita"
}

\begin{abstract}
ABSTRAK
Hasil tangkapan ikan di Danau Tondano cenderung menurun dari tahun ke tahun meskipun danau ini termasuk perairan dengan kesuburan sedang sampai tinggi (meso-eutrofik). Untuk meningkatkan produksi ikan di perairan tersebut, penelitian yang bertujuan untuk mengetahui karakteristik populasi ikan dan menetapkan telah dilakukan upaya rehabilitasinya. Karakteristik populasi ikan yang dipelajari meliputi komposisi jenis dan ukuran, distribusi. hubungan panjang-bobot, kebiasaan makan dan reproduksi. Pengambilan sampel ikan dilakukan dengan menggunakan gillnet percobaan di lima stasiun penelitian yang meliputi seluruh danau. Hasil penelitian menunjukkan bahwa komposisi hasil tangkapan didominasi oleh ikan introduksi, yaitu 42,8\% ikan payangka (Ophiorara porocephala), 19,6\% mujair (Oreochromis mossambicus), 9.8\% gabus (Channa striatus) dan 6.2\% ikan mas (Cyprinus corpio). Ukuran ikan yang tertangkap umumnya kecil dengan kelompok umur yang relatif masih muda. Ikan payangka, ikan mas dan mujair mempunyai distribusi yang luas sedangkan distribusi ikan lainnya terbatas di daerah tertentu. Ikan payangka termasuk ikan karnivor. mujair termasuk detri-planktivor. gabus termasuk piscivor dan ikan mas omnivor di mana tumpang tindih dan kompetisi pakan antar jenis ikan tersebut rendah. Ikan payangka memijah mulai bulan September sampai Januari dengan frekuensi pemijahan beberapa kali dalam satu musim pemijahan. sehingga ikan tersebut mampu hidup dan berkembang biak dengan baik. Untuk peningkatan produksi ikan, upaya rehabilitasi yang perlu dilakukan meliputi penebaran ulang ikan. penetapan reservat, pengaturan penangkapan, budi claya ikan dan tata ruang danau.
\end{abstract}

ABSTRACT: Fish population characteristics of Lake Tondano, North Sulawesi. By: Endi Setiadi Kartamihardja, Hendra Satria and Achmad S. Sarnita.

Fish yield of lake Tondano tends to derrease from year to year, eventhough the lake is classified into a meso-eutrophirewaters. In order to increase the fish yield, a study aimed to investigate fish population rharacteristic's and to establish an alternative effort for its rehabilitation was carried out. Fish population characteristics studied were fish romposition, distribution, length-uright relationship, feeding habits and roproduction. Fish population was sampled using experimental gillnet at five stations all over the lake. The results showed that the dominant fish catch composed of introdured species i.e., Ophiocara porocephala $42.8 \%$, Oreochromis mossambicus $19.6 \%$,

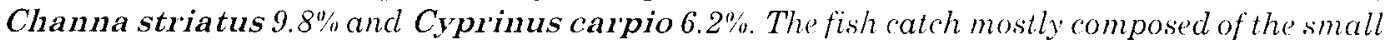
individual size with young age group. O. porocephala, O. mossambicus and C. carpiowere distributed all over the lake while others in a specific area. O. porocephala was classified into carnivor, O. mossambicus was detri-plantivor, C. striatus was piscivor and C. carpio was omnivor, where the overlaping niche and rompetition among the fish species was low. $O$. porocephala spawns from September to January with several spawning fiequencies in one sectson which yiclds in its well establish population. To increase the fish vield, rehabilitation of the population should include fish introduction and stoding, establishment of the fish resserve. fishing regulation. fish rulture and zoning of the lake.

\section{KEYWORDS: fish population, rehabilitation, management, lake}

\section{PENDAHULUAN}

Danau Tondano terletak di wilayah ibu kota Kabupaten Minahasa, Propinsi Sulawesi Utara, pada 124"40'-124"45' BT dan 1"12'-1"20' LU. Luas perairan danau ini adalah 4.600 ha dengan kedalaman rata-rata $16 \mathrm{~m}$. Di perairan ini ber. kembang usaha perikanan tangkap dan usaha budi daya ikan di keramba jaring apung. Usaha penangkapan ikan dilakukan oleh tidak kurang dari 1.000 orang nelayan, sedangkan usaha budi daya ikan dilakukan oleh 8.000 petani dengan jumlah keramba 4.000 unit (Dinas Perikanan Kabupaten Minahasa, 1996).

Hasil tangkapan ikan di Danau Tondano dari tahun ke tahun cenderung menurun. Produksi ikan pada tahun 1976 tercatat sebesar $3.027,1$ ton.

Peneliti padi Balai Penelitian Perikanan Air 'Tawar' 
produksi ini menurun dengan tajam dan pada tahun 1980 menjadi 1.907 ton, tahun 1983 sebesar 1.460,8 ton dan pada tahun 1986 hanya sebesar $1.084,3$ ton (Dinas Perikanan Kabupaten Minahasa, 1990). Meskipun belum diketahui secara pasti apakah terjadi tangkapan yang berlebih (over fishing), namun di samping hasil tangkapan nelayan yang cenderung menurun, ukuran ikan yang tertangkap pun cenderung mengecil. Padahal berdasarkan aspek biolimnologinya, perairan ini termasuk perairan subur dan cukup potensial untuk pengembangan perikanan (Umar \& Krismono, 1996).

Peningkatan produksi ikan di suatu perairan danau dapat dilakukan melalui rehabilitasi populasi ikannya yang disertai dengan rehabilitasi habitatnya. Swales \& O'Hara (1983) melaporkan bahwa kepadatan populasi ikan dace dan chub meningkat berturut-turut sebesar $75 \%$ dan $37 \%$ dari populasi awal setelah dilakukan perbaikan habitatnya.

Selain dimanfaatkan oleh perikanan, perairan Danau Tondano dimanfaatkan pula oleh sektor lain seperti pariwisata, perhubungan dan pembangkit tenaga listrik. Pemanfaatan danau oleh berbagai kegiatan tersebut akan berpengaruh terhadap perkembangan populasi ikan di perairan tersebut. Di antara kegiatan tersebut, pembangkit tenaga listrik diperkirakan akan berpengaruh langsung terhadap fluktuasi permukaan air danau dan biota perairannya untuk kemudian berlanjut terhadap perkembangan populasi ikan.

Penelitian ini bertujuan untuk mengetahui karakteristik populasi ikan dan habitatnya dalam rangka meningkatkan produksi ikan dan menetapkan alternatif rehabilitasi populasi ikannya.

\section{BAHAN DAN METODE}

\section{Stasiun Penelitian}

Metode penelitian yang digunakan adalah metode pengambilan contoh berstrata (stratified sampling method) (Nielson \& Johnson 1985), di mana Perairan Danau Tondano dibagi menjadi lima stasiun penelitian (Gambar 1).

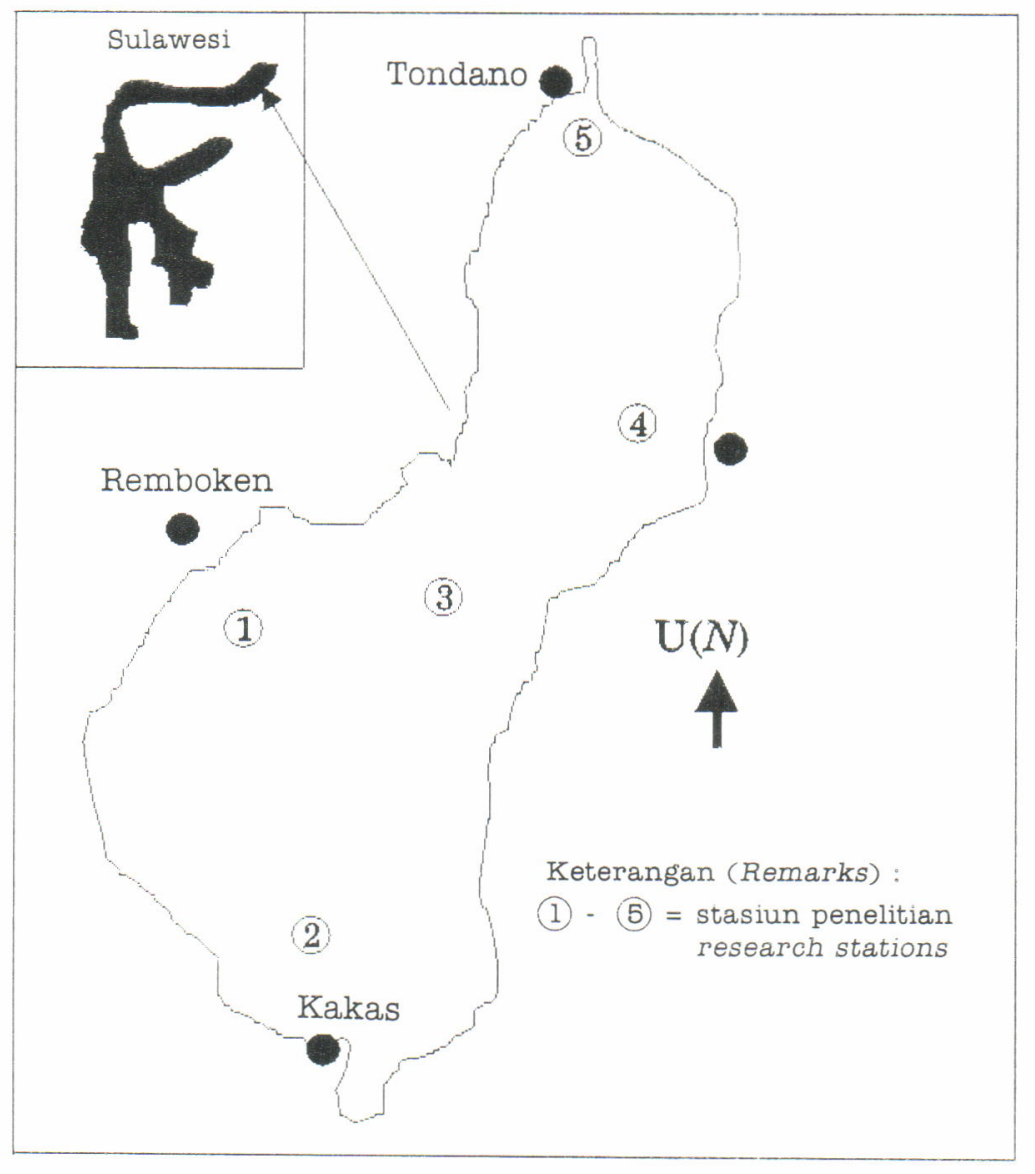

Gambar 1. Peta Danau Tondano dengan lima stasiun penelitiannya. Figure 1. Map of Lake Tondano showing the five sampling stations. 
Di setiap stasiun penelitian dilakukan percobaan penangkapan ikan, pengukuran kualitas air. pengambilan sampel plankton, benthos dan tumbuhan air. Di samping itu, dilakukan pula pengamatan hasil tangkapan ikan oleh nelayan di tempat pendaratan ikan dan pengamatan budi daya ikan di lokasi budi daya ikan dalam keramba jaring apung.

\section{Penelitian Karakteristik Populasi Ikan}

Karakteristik populasi ikan yang dipelajari meliputi komposisi jenis, kelimpahan relatif, distribusi, hubungan panjang-bobot, pakan alami dan kebiasaan makan dan reproduksi. Untuk mempelajari karakteristik populasi tersebut dilakukan penangkapan ikan dengan menggunakan gillnet percobaan (experimental gillnet). Sampel ikan yang tertangkap diukur panjang dan bobotnya, dan sebanyak $10 \%$ dari jumlah sampel diawetkan dengan formalin $10 \%$ untuk ikan ukuran kecil sampai sedang dan formalin $15 \%$ untuk ikan berukuran besar. Sampel ikan untuk pengamatan pakan alami dan kebiasaan makan serta reproduksi dibedah dan diambil lambung dan gonadnya. dimasukan ke dalam kantong plastik dan diawet dengan formalin $5 \%$. Pengamatan pakan alami ikan dihitung menggunakan metode jumlah (Hyslop, 1980) di mana isi perut ikan (lambung) diperiksa jenis makanannya. kemudian dicatat jumlahnya dan hasil keseluruhannya dihitung dalam persen. Tingkat kematangan gonad ditentukan berdasarkan klasifikasi Effendie (1979). Fekunditas ikan dihitung berdasarkan metode Nikolsky (1963) dengan persamaan sebagai berikut:

$$
F_{t o t}=\frac{B_{g t}}{B_{g}} \times F_{r}
$$

di mana $F_{: m i}=$ fekunditas total: $B_{a t}=$ bobot gonad total: $B_{\text {or }}=$ bobot gonad contoh: dan $\mathrm{F}_{\mathrm{c}}=$ fekunditas contoh. Indeks kematangan gonad (IKG) dihitung dari persamaan sebagai berikut:

$$
\operatorname{IKCr}=\frac{\mathrm{B}_{g}}{\mathrm{~B}_{\mathrm{r}}} \times 100 \%
$$

di mana $B_{2}=$ bobot gonad dan $B_{1}=$ bobot total ikan.

Di samping data hasil penangkapan ikan dengan menggunakan gillnet percobaan, sebagai data penunjang dilakukan pula pencatatan data hasil tangkapan nelayan dan data budi daya ikan dalam keramba jaring apung. Data dicatat pada blanko pertanyaan yang telah disediakan dengan metode wawancara. Jumlah responden nelayan adalah sebanyak 26 orang dan petani budi clay ikan dalam keramba sebanyak 20 orang yang ditentukan secara acak.

\section{Penentuan Karakteristik Habitat}

Karakteristik Danau Tondano yang diteliti meliputi kualitas air, plankton, benthos dan makrofita. Data tersebut diperlukan sebagai clata penunjang yang akan digunakan dalam upaya rehabilitasi populasi ikan di perairan tersebut.

Analisis kualitas air dilakukan di lapang (in situ) dan di laboratorium. Parameter kualitas air yang diamati di lapang adalah kandungan $\mathrm{O}_{2}, \mathrm{CO}_{2}$. $\mathrm{pH}$, alkalinitas, suhu, kecerahan dan konduktivitas. Sedangkan analisis kandungan fosfat, nitrat, sulfat dan bahan organik dilakukan di laboratorium. Analisis kualitas air di lapangan dilakukan dengan cara titrasi dan penggunaan alat DO meter. serta Secchi disk. Sampel air dan plankton diambil menggunakan botol Kemmerer volume satu liter di setiap stasiun pada permukaan air, lapisan pertengahan dan di lapisan dasar perairan.

Sampel plankton disaring dengan plankton net no. 25 dan dimasukkan ke dalam botol plankton bervolume $20 \mathrm{~mL}$ kemudian diawetkan dengan formalin $5 \%$. Pengamatan jenis dan jumlah plankton dilakukan di laboratorium menggunakan mikroskop binokuler. Jenis plankton diidentifikasi menggunakan buku Needham \& Needham (196;3). dan Edmonson (1959). Kelimpahan plankton dihitung berdasarkan metode Edmonson \& Winberg (1971).

Pengamatan benthos hanya dilakukan secara kualitatif clari jenis yang termasuk makro-bent hos.

Makrofita (tumbuhan air) diamati di seluruh perairan danau, dicatat jenis dan kelimpahan relatifnya per satuan luas tertent u.

\section{HASIL DAN BAHASAN}

\section{Karakteristik Populasi Ikan}

\section{Jenis, kelimpahan dan distribusi ikan}

Hasil percobaan penangkapan dengan menggunakan jaring insang didapat komposisi jenis ikan dan distribusinya seperti tertera pada Tabel 1.

Jenis ikan yang mendominasi hasil tangkilpan gillnet adalah ikan payangka, mujair, nila dan gabus. Ikan payangka, mujair dan mas mempunvali distribusi yang luas meliputi seluruh perairan. sedangkan jenis ikan lainnya hanya terbatati di 
Tabel 1. Komposisi dan distribusi ikan hasil tangkapan gillnet percobaan di Danau Tondano. Table 1. Species composition and distribution of the experimental gillnet catch at Lake Tondano.

\begin{tabular}{|c|c|c|c|c|c|c|}
\hline \multirow{2}{*}{$\begin{array}{l}\text { Jenis ikan } \\
\text { Fish species }\end{array}$} & \multirow{2}{*}{$\begin{array}{c}\text { Komposisi ikan } \\
\text { Fish composition } \\
(\%)\end{array}$} & \multicolumn{5}{|c|}{$\begin{array}{l}\text { Stasiun penelitian } \\
\text { Sampling station }\end{array}$} \\
\hline & & I & II & III & IV & $\mathrm{V}$ \\
\hline Payangka (Ophiocara porocephala) & 42.8 & - & - & - & - & - \\
\hline Mujair (Oreochromis mossambicus) & 19.6 & - & - & · & - & • \\
\hline Nila (Oreochromis niloticus) & 8.5 & $\cdot$ & · & * & - & * \\
\hline Gabus (Channa striatus) & 9.8 & - & - & * & * & • \\
\hline Nilem (Osteochilus hasselti) & 4.2 & $*$ & $\cdot$ & - & $*$ & * \\
\hline Sepat (Trichogaster trichopterus) & 5.0 & * & - & - & * & * \\
\hline Mas (Cyprinus carpio) & 6.2 & - & - & - & . & * \\
\hline Tawes (Barbodes gonionotus) & 1.2 & * & $\cdot$ & - & - & * \\
\hline Lele putih (Clarias batrachus) & 1.6 & * & . & * & * & • \\
\hline Grass carp (Ctenopharyngodon idellus) & 1.1 & * & $\cdot$ & * & - & * \\
\hline
\end{tabular}

- = terdapat (found): * = tidak terdapat (not found)

beberapa stasiun penelitian. Jenis dan kelimpahan relatif ikan hasil tangkapan nelayan yang dicatat di tempat pendaratan ikan tertera pada Tabel 2 .

Dibandingkan dengan ikan hasil tangkapan gillnet percobaan terdapat sedikit perbedaan dalam komposisi dan kelimpahan jenis ikan yang tertangkap. Hasil tangkapan nelayan terdapat 14 jenis ikan dan ikan lele juga merupakan jenis yang mendominasi sedangkan hasil tangkapan gillnet percobaan hanya tertangkap sebanyak 10 jenis ikan dan ikan lele tidak merupakan jenis yang dominan. Hal ini dapat dimengerti karena alat tangkap yang digunakan nelayan lebih banyak jenisnya, selain gillnet terdapat juga jala, pancing rawai, bubu dan tombak.

Jenis ikan yang hidup dan berkembang di Danau Tondano hampir seluruhnya merupakan ikan introduksi sehingga seperti kebanyakan danau di Sulawesi, kegiatan usaha penangkapan ikannya didasarkan kepada jenis ikan introduksi bukan ikan asli (indigenous species) di perairan tersebut. Sejak tahun 1895, sebanyak 11 jenis ikan telah diintroduksikan ke Danau Tondano (Tabel 2). Dewasa ini dari 11 jenis ikan introduksi tersebut, ikan payangka yang didatangkan dari Danau Limboto merupakan jenis ikan yang paling dominan dalam tangkapan nelayan. Sedangkan ikan asli yang dapat berkembang biak dengan baik hanya ikan gabus. Hasil tangkapan nelayan berikutnya didominasi oleh ikan mujair, ikan mas dan sepat siam. Di samping ikan, tertangkap pula udang yang berukuran relatif kecil dari famili Mystidacea.

\section{Hubungan panjang-bobot}

Hubungan panjang-bobot ikan hanya dihitung untuk ikan payangka, mujair dan sepat, yaitu:

(1) Ikan payangka jantan: $\log \mathrm{W}=-2,00747+$ $3,10323 * \log \mathrm{L}(\mathrm{r}=0,96 ; \mathrm{n}=67)$

(2) Ikan payangka jantan: $\log W=-1,27663+$ $2,41654^{*} \log \mathrm{L}(\mathrm{r}=0,96 ; \mathrm{n}=44)$

(3) Ikan mujair: $\log W=-1,02677+2,26271 * \log \mathrm{L}$ $(r=0,92 ; n=34)$

(4) Ikan sepat: $\log W=-1,94508+3,14307^{*} \log \mathrm{L}$ $(\mathrm{r}=0,95 ; \mathrm{n}=17)$

Dari persamaan hubungan panjang-bobot tersebut terlihat bahwa nilai b untuk ikan payangka betina dan ikan mujair berbeda nyata dengan 3 sehingga pertumbuhannya termasuk allometrik. Sedangkan pertumbuhan ikan payangka jantan dan ikan sepat termasuk pertumbuhan isometrik.

Distribusi panjang total ikan payangka, mujair dan sepat tertera pada Gambar 2. Distribusi panjang total tersebut memperlihatkan bahwa populasi ikan payangka, mujair dan sepat yang tertangkap didominasi oleh ukuran ikan yang masih muda (berukuran kecil). Hal ini menandakan bahwa intensitas penangkapan terhadap populasi ikan tersebut cukup intensif.

\section{Pakan alami dan kebiasaan makan}

Dari hasil tangkapan dengan jaring insang percobaan, jenis-jenis ikan yang dianalisis pakan 
Tabel 2. Jenis dan kelimpahan relatif ikan hasil tangkapan nelayan di Danau Tondano.

Table 2. Fish species and relative densities of fisher catch at lake Tondano.

\begin{tabular}{|c|c|c|}
\hline $\begin{array}{c}\text { Jenis ikan } \\
\text { Fish species }\end{array}$ & $\begin{array}{c}\text { Kelimpahan relatif } \\
\text { Relative density }\end{array}$ & $\begin{array}{c}\text { Keterangan } \\
\text { Remarks }\end{array}$ \\
\hline Payangka (Ophiocara porocephala) & $\cdots$ & $\begin{array}{c}\text { Diintroduksi } \\
\text { Introduced (1902) }\end{array}$ \\
\hline Mujair (Oreochromis mossambicus) & $\cdots$ & $\begin{array}{c}\text { Diintroduksi } \\
\text { Introduced (1951) }\end{array}$ \\
\hline Nila (Oreochromis niloticus) & $\cdots$ & $\begin{array}{c}\text { Diintroduksi } \\
\text { Introduced (1971) }\end{array}$ \\
\hline Gabus (Channa striatus) & $\cdots$ & Indigenous sp. \\
\hline Nilem (Osteochilus hasselti) & • & $\begin{array}{c}\text { Diintroduksi } \\
\text { Introduced (1941) }\end{array}$ \\
\hline Sepat siam (Trichogaster trichopterus) & $\cdots$ & $\begin{array}{c}\text { Diintroduksi } \\
\text { Introduced (1938) }\end{array}$ \\
\hline Sepat jawa (Trichogaster pectoralis) & · & $\begin{array}{c}\text { Diintroduksi } \\
\text { Introduced (1938) }\end{array}$ \\
\hline Mas (Cyprinus carpio) & $\cdots$ & $\begin{array}{c}\text { Diintroduksi } \\
\text { Introduced (1895) }\end{array}$ \\
\hline Tawes (Barbodes gonionotus) & - & $\begin{array}{c}\text { Diintroduksi } \\
\text { Introduced (1954) }\end{array}$ \\
\hline Lele putih (Clarias batrachus) & $\cdots$ & $\begin{array}{c}\text { Diintroduksi } \\
\text { Introduced (1975) }\end{array}$ \\
\hline Grass carp (Ctenopharyngodon idellus) & - & $\begin{array}{c}\text { Diintroduksi } \\
\text { Introduced (19..) }\end{array}$ \\
\hline Gurame (Osphronemus gouramy) & $\cdots$ & $\begin{array}{c}\text { Diintroduksi } \\
\text { Introduced (1914) }\end{array}$ \\
\hline Sidat (Anguilla sp.) & · & Indigenous sp. \\
\hline Belut (Fluta alba) & • & Indigenous sp. \\
\hline
\end{tabular}

$\cdots=$ banyak $(>50 \%$ total tangkiapan) many (> 50\% of total (atch):

.. = cukup banyak (26-50\% total tangkapan) moderate (26-50\% of total catch):

. = jarann (5-25\% total tangkapan) rare $(5-25 \%$ of total catch);

- = sangat jarang (<5\%/3 total tangkapan) very rare $<5 \%$ of total ratch)

alaminya adalah ikan payangka, mujaer, gabus, sepat dan lele. Hasil analisis dengan metode jumlah menunjukkan bahwa ikan payangka dan lele termasuk ke dalam golongan ikan karnivor dengan makanan utamanya moluska, ikan gabus termasuk ke dalam golongan ikan predator dengan makanan utamanya anak ikan, ikan mujair termasuk golongan detritivor dan planktivor karena makanan utamanya terdiri atas detritus dan plankton sedangkan sepat termasuk herbivorplanktivor dengan makanan utamanya makrofita dan plankton (Tabel 3).
Ikan payangka termasuk jenis ikan yangaktif mencari makan dan mempunyai luas relung (niche) pakan yang paling besar. Kompetisi clalam pemanfaatan pakan alami yang tersedia di antara jenis ikan sangat rendah karena tumpang tindih dalam relung pakan alami tidak terlihat nyata. Pianka (1974) melaporkan bahwa tumpang tindih relung makanan terjadi jika terdapat dua organisme atau lebih yang memanfaatkan sumber daya makanan yang sama. Hal ini diduga merupa. kan salah satu faktor penyebab keberhasilan perkembangan populasi ikan payangka di Danau 


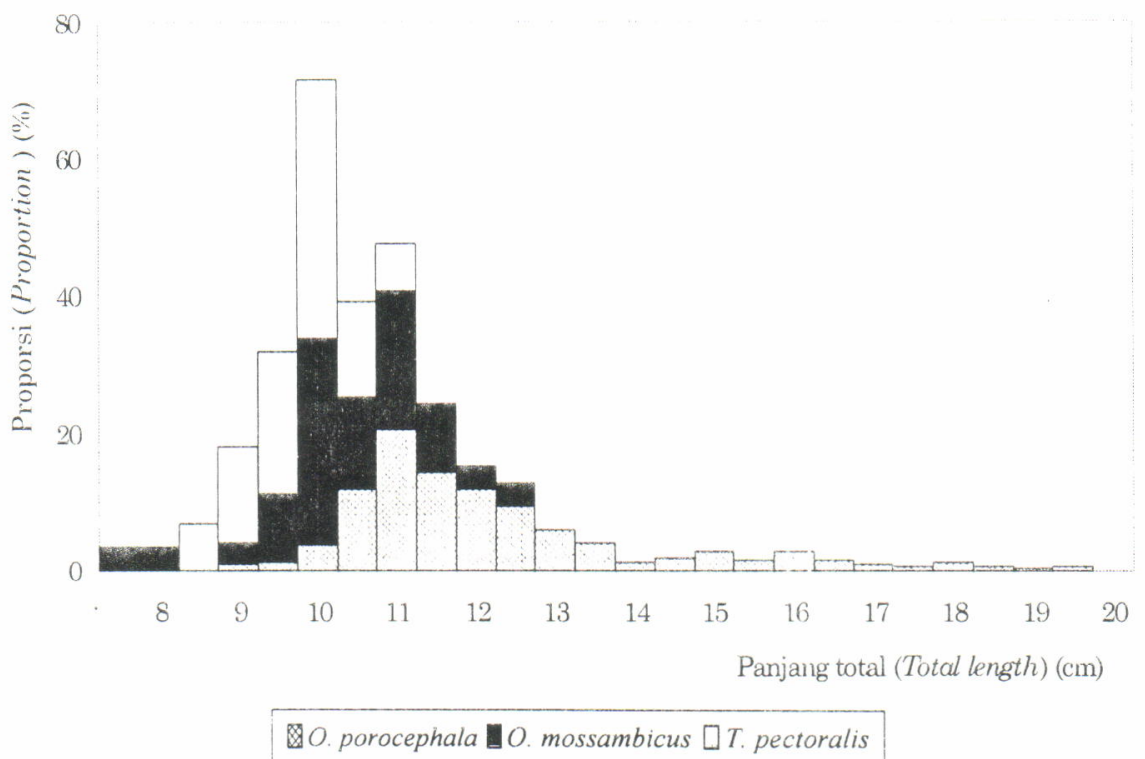

Gambar 2. Frekuensi distribusi panjang total ikan payangka, mujair dan sepat.

Figure 2. Total length frequency distribution of O. porocephala, O. mossambicus and T. pectoralis.

Tondano. Faktor lain penyebab keberhasilan perkembangan populasi ikan payangka adalah fekunditasnya yang tinggi dan rendahnya populasi predator (terutama ikan gabus) yang makanan utamanya terdiri atas anak ikan payangka atau yang oleh masyarakat setempat disebut ikan nike.

\section{Fekunditas}

Aspek reproduksi ikan yang meliputi kematangan gonad, indeks kematangan gonad, fekunditas, musim dan tempat pemijahan hanya diamati terhadap ikan payangka, karena jumlah sampel dari jenis ikan yang lain tidak memenuhi syarat. Dari sampel sebanyak 114 ekor terdiri atas 47 ekor betina dan 67 ekor jantan, sebanyak 16 ekor ikan betina menunjukkan kondisi yang sudah matang gonad. Indeks kematangan gonad ikan payangka berdasarkan tingkat kematangannya dan ukuran ikan tertera pada Tabel 4.

Pada TKG I dan II yaitu di mana gonad ikan masih berkembang mempunyai nilai rata-rata

Tabel 3. Komposisi pakan alami (\% jumlah) jenis ikan dominan di Danau Tondano.

Table 3. Fish diet composition (\% number) of the dominant speries at Lake Tondano.

\begin{tabular}{|c|c|c|c|c|c|}
\hline \multirow{2}{*}{$\begin{array}{l}\text { Jenis pakan } \\
\text { Food items }\end{array}$} & \multicolumn{5}{|c|}{ Jenis ikan (Fish species) } \\
\hline & O. porocephala & O. mossambicus & C. striatus & T. trichopterus & C. batrachus \\
\hline Moluska (Mollusc) & 48.0 & . & & - & 28.0 \\
\hline Udang (Shrimp) & 16.4 & - & 17.8 & - & 14.8 \\
\hline Larva insecta (Insect larvae) & 4.8 & - & 10.5 & - & 12.2 \\
\hline Makrofita (Macrophyte) & 6.0 & 2.5 & 2.2 & 47.5 & - \\
\hline Detritus (Detritus) & 3.7 & 46.0 & - & 2.8 & 15.4 \\
\hline Plankton (Plankton) & 17.0 & 37.5 & - & 44.2 & - \\
\hline Anak ikan (Fish fry) & 2.1 & - & $6(0.5$ & $\cdot$ & 18.6 \\
\hline $\begin{array}{l}\text { Bahan tidak teridentifikasi } \\
\text { Unidentified matterial }\end{array}$ & 2.0 & 5.0 & 9.0 & 5.5 & - \\
\hline $\begin{array}{l}\text { Total sampel (Sample } \\
\text { number) }\end{array}$ & 19 & 9 & 4 & 5 & 5 \\
\hline
\end{tabular}


Tabel 4. Indeks kematangan gonad dan fekunditas ikan payangha.

Table 4. Gonado somatic index and fecundity of $O$. porocephala.

\begin{tabular}{cccccccc}
\hline \multirow{2}{*}{$\begin{array}{c}\text { TKG } \\
\text { Tonado } \\
\text { stage }\end{array}$} & Sampel & Sample & \multicolumn{2}{c}{$\begin{array}{c}\text { Bobot tubuh }(\mathrm{g}) \\
\text { Body weight }(g)\end{array}$} & \multicolumn{2}{c}{$\begin{array}{c}\text { IKG }(\%) \\
\text { GSI }(\%)\end{array}$} & \multicolumn{2}{c}{$\begin{array}{c}\text { Fekunditas } \\
\text { Fecundity }\end{array}$} \\
\cline { 3 - 8 } & & Range & $\begin{array}{c}\text { Rata-rata } \\
\text { Average }\end{array}$ & $\begin{array}{c}\text { Kisaran } \\
\text { Range }\end{array}$ & $\begin{array}{c}\text { Rata-rata } \\
\text { Average }\end{array}$ & $\begin{array}{c}\text { Kisaran } \\
\text { Range }\end{array}$ & $\begin{array}{c}\text { Rata-rata } \\
\text { Average }\end{array}$ \\
\hline \multirow{2}{*}{ I } & 21 & $12-18$ & 14.6 & $1.9-2.3$ & 1.96 & - & - \\
II & 10 & $14-23$ & 17.0 & $2.4-2.6$ & 2.45 & - & - \\
III & 9 & $18-49$ & 25.3 & $2.8-2.9$ & 2.85 & $11,355-46.350$ & 28.003 \\
IV & 7 & $18-44$ & 30.8 & $3.0-4.1$ & 3.52 & $32,870-48,750$ & 37.73 \\
\hline
\end{tabular}

masing-masing sebesar $1,96 \%$ dan $2,45 \%$. Indeks ini terus meningkat sejalan dengan berkembangnya gonad dan indeks tersebut dapat digunakan untuk memprediksi kapan ikan tersebut akan atau siap melakukan pemijahan. Turner \& Summerfelt dalam Hall (1971) melaporkan bahwa saat pemijahan pertama kali dapat ditafsirkan dari perubahan Indeks Kematangan Gonad (IKG). Dengan demikian, ikan payangka di Danau Tondano diduga akan melakukan pemijahan pada IKG antara $3,0-4,1 \%$

Fekunditas ikan payangka pada TKG IV (telur yang akan dipijahkan) berkisar antara 32.870 . 48.750 butir dengan rata-rata 37.730 butir, pada panjang total $11,2-15.2$ dengan rata-rata $13,3 \mathrm{~cm}$. Fekunditas ini lebih besar dari fekunditas ikan payangka di Danau Limboto dengan rata-rata 12.172 butir telur, pada panjang total rata-rata 7,7 cm (Satria, 1997). Sedangkan Soeroto (1988) melaporkan bahwa ikan payangka mempunyai fekunditas total antara 30.000-60.000 butir pada kisaran panjang total $8,6-20.5 \mathrm{~cm}$.

Sebaran diameter telur ikan payangka pada TKG IIJ dan IV terdiri atas tiga kelompok (Gambar 3).

Kelompok I mempunyai kisaran diameter telur 139,2-197,2 mm. Telur pada kelompok ini terlihat transparan dan berwarna sedikit kekuningan. Kelompok II mempunyai kisaran diamater telur 208,8-278,4 mm dan merupakan kelompok telur yang terbanyak, yaitu sebesar $80 \%$ dari total telur matang. Sedangkan kelompok III mempunyai kisaran diameter telur 290,0-324,8 mm dengan jumlah sekitar $7 \%$ dari total telur matang. Sebaran diameter telur tersebut dapat digunakan untuk menduga frekuensi pemijahan. Jika sebaran diameter telur berukuran relatif sama (mempunyai satu modus) maka frekuensi pemijahan tersebut pendek, sedangkan frekuensi pemijahan ikan akan lama dan terus-menerus jika sebaran diameter telurnya berbeda-beda (Wotton, 1989).

Ikan payangka dengan TKG III dan IV banyak terdapat pada bulan Juli dan September yaitu masing-masing sebesar $19 \%$ dan $16 \%$ dari total ikan yang tertangkap. Hal ini mengindikasikan bahwa ikan payangka diduga memijah di antara bulan. bulan tersebut dengan frekuensi pemijahan beberapa kali dalam setahun. Sesuai dengan yang dilaporkan Soeroto (1988), puncak pemijahan ikan payangka diduga terjadi pada bulan Juli, September dan Desember, di mana pada bulan-bulan tersebut di Tondano termasuk musim kemarau. Musim pemijahan ikan payangka ini berbeda dengan musim pemijahan hagi kebanyakan jenis ikan di daerah tropis yang biasanva memijah pada musim penghujan.

Tempat pemijahan ikan payangka diduga terjadi di daerah-daerah yang terlindung dari hembusan ombak dan arus serta banyak terdapat tumbuhan air. Hal inj didukung dengan melimpahnya anak ikan payangka di daerah tersebut seperti di daurah Remboken. Kakas dan Touliang Oki. Anak anak ikan payangka yang menyukai daerah yang banyak tumbuhan air ini dimanfaatkan oleh nelayan dalam penangkapan nike tersebut dengan cara membuat rumpon. P'nangkapan nike yang intensif ini sudah tentu akan mengganggu populasi ikan pavangku. oleh sebab itu upaya pengelolaan perikanan khususnya yang menyangkut penangkapan ikan nike harus dibatasi.

\section{Status Perikanan}

\section{Penangkapan ikan}

Usaha penangkapan ikan di Dunau 'Tondanos dilakukan oleh sekitar 1.000 orangr nelayan yang 


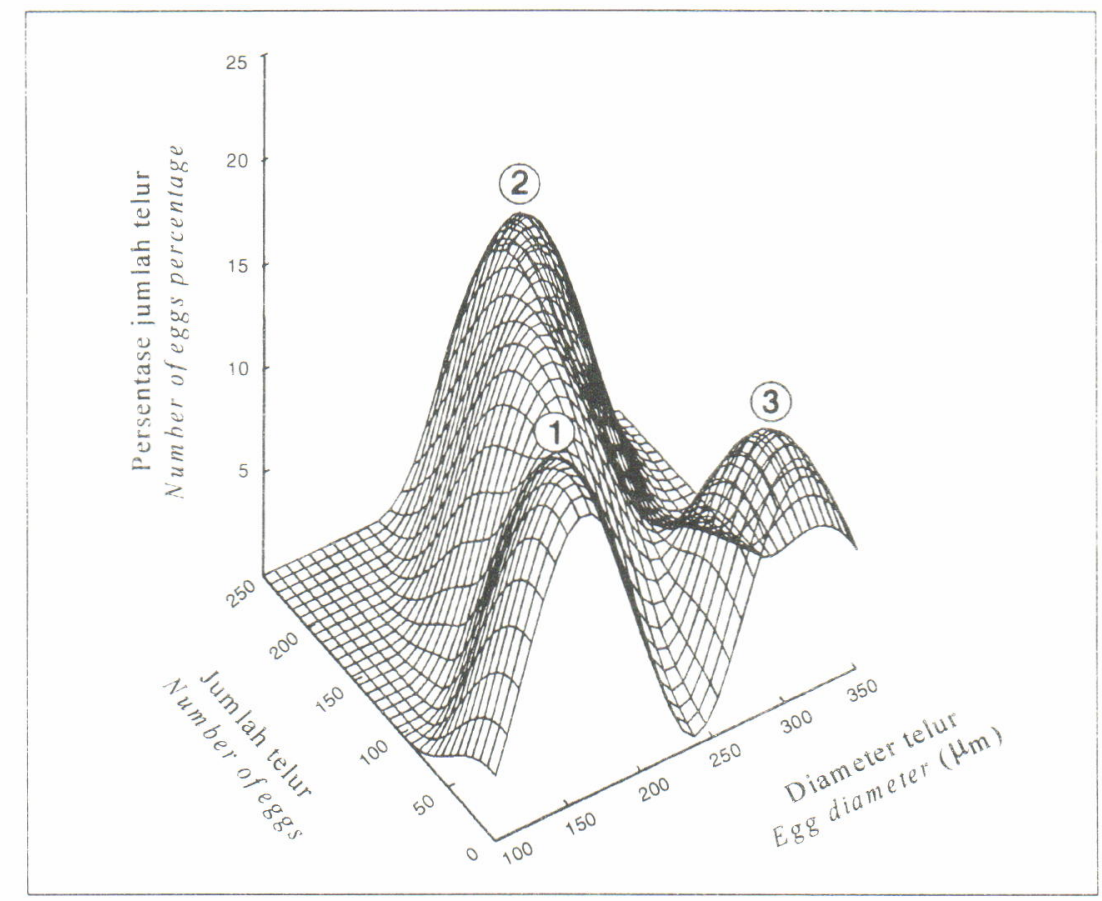

Gambar 3. Sebaran kelompok diameter telur ikan payangka.

Figure 3. Distribution of egg diameter of $O$. porocephala.

tersebar di empat kecamatan, yaitu Kecamatan Eris, Kakas, Remboken dan Tondano. Kecamatan Eris merupakan kecamatan yang terpadat jumlah nelayannya. Jenis alat tangkap yang digunakan adalah jaring insang, pancing rawai, jala, seser, anco dan tombak. Alat tangkap ikan pada umumnya dioperasikan di daerah litoral yang tidak dalam dan tidak jauh dari pantai. Alat tangkap yang paling banyak digunakan adalah jaring insang dengan ratarata hasil tangkapan berkisar antara $10-15 \mathrm{~kg} /$ hari/ bal jaring. Satu bal jaring terdiri atas empat lembar jaring masing-masing berukuran panjang 30-35 m dengan kedalaman 1,5 m. Pancing rawai dan tombak terutama digunakan untuk menangkap ikan gabus, sedangkan anco dan seser digunakan untuk menangkap ikan berukuran kecil terutama nike dan udang.

Pada tahun 1996, berdasarkan perhitungan jumlah nelayan yang beroperasi dan rata-rata hasil tangkapan per upaya (CPUE)-nya, produksi ikan Danau Tondano diperkirakan hanya sebesar 484 ton atau rata-rata $105 \mathrm{~kg} / \mathrm{ha} /$ tahun. Produksi ikan ini jauh menurun jika dibandingkan dengan produksi ikan pada tahun 1976 yang tercatat sebesar 3.027,1 ton. Produksi ikan yang tinggi nampaknya hanya terjadi setelah dilakukan introduksi ikan dan setelah itu produksi ikan menurun kembali. Penurunan produksi ikan tersebut mengindikasikan bahwa pengelolaan perikanan di perairan ini belum berjalan dengan baik.

\section{Budi daya ikan}

Usaha budi daya ikan yang banyak dilakukan adalah budi daya ikan dalam keramba jaring dengan tiang penyangga jaring yang ditancapkan ke dasar perairan. Ukuran keramba jaring yang digunakan pada umumnya adalah 3,5 × 3,5 × 2,5 $\mathrm{m}^{3}$. Jumlah keramba jaring ditaksir sekitar 4.000 unit dengan jumlah petani 295 orang. Jenis ikan yang dipelihara adalah ikan mas dan nila. Hasil wawancara dan pengamatan menunjukkan bahwa ikan nila yang dipelihara mutunya sudah menurun dan pertumbuhannya lambat. Hal ini ditunjukkan antara lain dengan pertumbuhan ikan nila yang baru mencapai 250-300 g per ekor selama pemeliharaan enam bulan dengan konversi pakan yang tinggi yaitu antara 2,5-3,0 meskipun ikan tersebut diberi pakan berbentuk pellet dengan kandungan protein 26\%. Produksi ikan nila berkisar antara $350-500 \mathrm{~kg} / \mathrm{keramba} / 6$ bulan pemeliharaan dari awal penebaran antara 1500 . 2000 ekor/keramba ukuran 10-15 g/ekor.

Berbeda dengan ikan nila, ikan mas yang dipelihara umumnya dari galur Punten dan mempunyai kualitas yang relatif lebih baik. Ikan mas umumnya diberi pakan berupa cacahan daging kijing yang populasinya melimpah. Benih ikan mas yang ditebar berukuran 50-60 ekor per kg atau ratarata 15-20 g per ekor. Satu unit keramba yang ditebari $150($ ) ekor benih atau antara 250-300 kg 
dapat menghasilkan ikan sebesar $1500 \mathrm{~kg}$ selama masa pemeliharaan 2,5-3 bulan.

\section{Karakteristik Habitat}

Berdasarkan karakteristik fisika-kimiawi airnya (Tabel 5), Danau Tondano termasuk perairan dengan kesuburan sedang sampai tinggi (mesoeutrofik). Kualitas air antar stasiun tidak menunjukkan perbedaan yang mencolok kecuali kandungan fosfat dan bahan organik di daerah Eris (daerah budi daya ikan) lebih tinggi dari pada stasiun lainnya. Hal ini sebagai dampak dari buangan kegiatan budi daya ikan baik dalam bentuk kotoran ikan maupun sisa pakan yang terbuang.
Di Danau Tondano terdapat tidak kurang dari 10 jenis makrofita, baik yang tenggelam (submerged) maupun yang terapung (floating). Kelimpahan relatif dari jenis-jenis makrofita tersebut tertera pada Tabel 6. Jenis makrofita yang tenggelam ditemukan hampir di seluruh bagian littoral perairan, sedangkan makrofita yang mengapung hanya terdapat di beberapa teluk, di daerah Remboken, Kakas dan Tondano. Makrofita ini membentuk mikro habitat komplek yang berguna dalam penyediaan tempat berlindung (shelter) hewan air, substrat mikroorganisme dan berperan sebagai faktor homeostatik dalam proses dekomposisi bahan organik. Ikan memanfait kan makrofita untuk tempat berlindung.

Tabel 5. Karakteristik fisika-kimiawi air Danau Tondano.

Table 5. Physico-chemical characteristics of Lake Tondano.

\begin{tabular}{|c|c|c|c|c|c|}
\hline \multirow{2}{*}{ Parameter } & \multicolumn{5}{|c|}{ Stasiun penelitian (Sampling station) } \\
\hline & I & II & III & IV & $\mathrm{V}$ \\
\hline Suhu air (Temperature) ("C) & $27.0-29.5$ & $26.5-28.0$ & $26.5-28.5$ & $27.0-28.5$ & $27.0-28.0$ \\
\hline Konduktivitas (Conductivity) (ohm/cm) & $185-200$ & $180-205$ & $190-210$ & $195-225$ & $190-200$ \\
\hline Kecerahan (Transparency) (cm) & $200-220$ & $180-220$ & $200-220$ & $190-240$ & $180-200$ \\
\hline $\mathrm{pH}$ (unit) & $6.8-7.2$ & $6.7 \cdot 7.0$ & $6.6-7.7$ & $7.4-7.6$ & $7.8-8.0$ \\
\hline Kelarutan $\mathrm{O}_{2}(D O)(\mathrm{mg} / \mathrm{L})$ & $6.1-7.4$ & $6.5-9.2$ & $5.0-8.2$ & $4.4-8.6$ & $7.0-9.8$ \\
\hline $\mathrm{CO}_{2}(\mathrm{mg} / \mathrm{L})$ & $1.2-4.2$ & $0.6-2.4$ & $1.6-3.5$ & $1.8-4.4$ & $0.5-1.2$ \\
\hline Alkalinitas (Alkalinity) (mg/L $\mathrm{CaCO}: \mathrm{eq})$ & $65-85$ & $72-90$ & $75-98$ & $72-86$ & $56-68$ \\
\hline Nitrat (Nitrate) $(\mathrm{mg} / \mathrm{L})$ & $0.32-0.54$ & $0.15-() .46$ & $0.17-0.35$ & $0.18-0.41$ & $0.12-0.11$ \\
\hline Fosfat (Phosphate) (mg/L) & $0.12-0.94$ & $1.06-1.28$ & $0.15-0.88$ & $0.86-1.68$ & $0.65-0.81$ \\
\hline Sulfat (Sulfate) (mg/L) & $1.22 \cdot 1.82$ & $0.79-1.69$ & $1.35-2.24$ & $1.24-2.55$ & $0.69-0.98$ \\
\hline $\begin{array}{l}\text { Bahan Organik Total (Total Organic } \\
\text { Matter) (mg/L, }\end{array}$ & $32.5-36.8$ & $30.6-36.2$ & $30.1-34.2$ & $34.2-38.5$ & $30.5-335.6$ \\
\hline
\end{tabular}

Kelimpahan plankton di perairan ini cukup tinggi. Fitoplankton terdiri atas 48 genera yang termasuk ke dalam enam famili dengan kelimpahan rata-rata 2.450 individu per liter. Jenis fitoplankton yang dominan adalah Straurastum, Cosmarium, Navicula dan Synedra. Zooplankton terdiri atas famili Copepoda yaitu Keratella, Nauplius dan Cyclops, serta famili Rotifera dari jenis Brachionus dengan kelimpahan rata-rata 96 individu per liter.

Produktivitas primer perairan Danau Tondano yang diukur dengan metode botol gelap-terang berkisar antara 35-160 mgC/m³/jam. Berdasarkan produktivitas primer tersebut, potensi perikanan danau ini diduga berkisar antara $60-185 \mathrm{~kg} / \mathrm{ha} / \mathrm{th}$. dan pakan, serta tempat menempelnya makanan ikan yang berupa perifiton maupun hewan kecil lainnya. Dengan demikian kehadiran makrofita terutama yang tenggelam merupakan sumber makanan ikin herbivora.

Kehadiran eceng gondok (Eichhornia crassipes) perlu segera dikendalikan karena makrofita tersebut mempunyai pertumbuhan dan perkembangan biak yang sangat cepat sehingga jika dibiarkan dengan cepat pula akan menjadi gulma yang merugikan.

Jenis makro-bentos yang paling banyak ditemukan adalah moluska, baik yang termasuk jenis gastropoda maupun bivalve (Tabel 7). Whitten 't al. (1988) menemukan sebanyak 10 jenis moluska 
Tabel 6. Jenis dan kelimpahan relatif makrofita di Danau Tondano. Table 6. Species and relative density of macrophytes in Lake Tondano.

$\begin{aligned} & \text { Jenis } \\ & \text { Species }\end{aligned}$
$\begin{aligned} & \text { Kelimpahan relatif } \\ & \text { Relative density }\end{aligned}$
Melayang (Sub merged):
Ceratophyllum demersum
Hydrilla verticillata
Najas indica
Potamogeton malainus

Tabel 7. Jenis dan kelimpahan relatif moluska yang terdapat di Danau Tondano. Table 7. Species and relative density of molluscs found in Lake Tondano.

\begin{tabular}{|c|c|c|}
\hline $\begin{array}{l}\text { Kelas } \\
\text { Class } \\
\end{array}$ & $\begin{array}{c}\text { Jenis } \\
\text { Species }\end{array}$ & $\begin{array}{l}\text { Kelimpahan relatif } \\
\text { Relative density }\end{array}$ \\
\hline \multirow[t]{11}{*}{ Gastropoda } & Pila ampullacea & ** \\
\hline & Neritina labiosa & $* *$ \\
\hline & Melanoides plicaria & * \\
\hline & Melanoides turbeculata & * \\
\hline & Thiara scabra & * \\
\hline & Anguligra costata & * \\
\hline & Lymnaea auricularia & $* *$ \\
\hline & Gyraulus tondanensis & $* * *$ \\
\hline & Physastra celebensi & $* *$ \\
\hline & Physastra minahassae & $\star *$ \\
\hline & Pomacea sp. & $* *$ \\
\hline Bivalva & Anodonta woodiana & $* * *$ \\
\hline
\end{tabular}


sedangkan pada penelitian ini ditemukan 12 jenis moluska. Dua jenis moluska baru yang ditemukan tersebut adalah siput murbai (Pomacea sp.) dan kijing (Anodontawoodiana). Kelimpahan A. woodiana yang tinggi banyak dimanfaatkan oleh petani ikan dalam keramba jaring sebagai pakan ikan mas. Keberadaan jenis moluska tersebut sangat bermanfaat juga dalam perbaikan kualitas air di dasar perairan karena kemampuannya dalam menyerap dan filtrasi bahan organik sebagai hasil buangan budi daya keramba jaring tancap.

\section{Rehabilitasi Populasi Ikan}

Rehabilitasi populasi ikan pada dasarnya ditujukan untuk memperbaiki struktur populasi ikan sehingga produksi ikan di perairan tersebut optimal sesuai dengan tingkat kesuburannya. Upaya rehabilitasi populasi ikan ini harus disertai pula dengan rehabilitasi habitatnya sehingga populasi ikan dapat tumbuh dan berkembang biak pada kondisi yang optimal. Berdasarkan karakteristik populasi ikan, status perikanan dan karakteristik habitat Danau Tondano seperti yang diuraikan terdahulu, maka rehabilitasi populasi ikan yang perlu dilakukan di perairan ini meliputi kegiatan sebagai berikut:

\section{(1) Introduksi dan atau penebaran ikan}

Melihat struktur komunitas ikan yang ada dewasa ini dan kesuburan perairannya, upaya introduksi ikan yang telah lama dilakukan perlu dilanjutkan. Jenis ikan yang perlu ditebarkan ulang adalah ikan nila, mas dan tawes. Ikan nila diharapkan dapat memanfaatkan kelimpahan plankton yang tinggi, ikan mas memanfaatkan moluska dan organisme benthos lainnya, dan ikan tawes dapat memanfaatkan makrofita yang banyak tersedia. Ketiga jenis ikan tersebut, terutama nila dan mas merupakan jenis ikan yang pasarannya cukup baik sehingga cocok sebagai ikan tangkapan komersial.

\section{(2) Pembentukan reservat perikanan}

Reservat perikanan yang ada sekarang dan telah ditetapkan oleh Dinas Perikanan setempat di daerah Remboken sudah lama tidak memenuhi syarat lagi. Reservat tersebut berada di daerah pariwisata dan lalu-lintas serta banyak ditumbuhi makrofita terutama eceng gondok dan ganggeng. Reservat perikanan perlu dipindahkan ke lokasi yang lebih sesuai. I)aerah Kakas (Gambar 4) diperkirakan akan memenuhi syarat sebagai reservat karena daerah tersebut berfungsi sebagai tempat pemijahan dan asuhan ikan ekonomis penting seperti ikan mas, nila. tawes. dan payangka.

\section{(3) Pengaturan penangkapan}

Pengaturan penangkapan ikan yang selama ini belum ada perlu ditetapkan, terutama mengenai pembatasan pemakaian alat tangkap yang bersifat mengeruk semua ukuran ikan, seperti penangkap. an anak ikan payangka (nike) dan pemakaian jaring insang dengan ukuran mata kurang dari 1 cm. Monitoring hasil tangkapan dan pengawasan penangkapan ikan juga perlu dilakukan. Hal ini penting untuk mengevaluasi keberhasilan introduksi atau penebaran ulang, sehingga rencana pengelolaan populasi ikan selanjutnya dapat ditetapkan

\section{(4) Penentuan tata ruang perikanan}

Danau Tondano merupakan perairan yang bersifat serbaguna untuk perikanan, pengairan. pariwisata, perhubungan dan pembangkit tenaga listrik. Mengingat fungsi serbaguna tersebut. maka tataruang perairan untuk perikanan perlu dilakukan.untuk menghindari terjadinya konf'lik di antara pengguna perairan dan fungsi lokasi kegiatan perikanan. Untuk kepentingan perikanan perlu ditetapkan alokasi wilayah untuk budi daya ikan, penangkapan ikan dan reservat sumber daya ikan seperti pada Gambar 4. Penetapan tata ruang tersebut dapat dilakukan melalui penetapan peraturan daerah (PERDA) tingkat II Minahasa.

\section{KESIMPULAN}

1. Struktur populasi ikan di Danau Tondano didominasi oleh jenis ikan introduksi vaitu payangka, mujair, ikan mas dan sepat: sedangkan ikan asli yang dominan hanya ikan gabus. Struktur populasi ikan berada dalam keadaan seimbang dengan tingkat kompetisi makanan yang rendah.

2. Danau Tondano termasuk perairan dengan kesuburan sedang sampai tinggi dengan potensi produksi ikan antara $60-150 \mathrm{~kg} / \mathrm{ha} / \mathrm{th}$. Produksi ikan tangkapan masih dapat ditingkatkan melalui rehabilitasi populasi ikannya. Usaha budi daya ikan nila dalam keramba jaring dapat ditingkatkan produktivitasnya melalui introcluksi ikan rila yang mempunyai pertumbuhan dan efisiensi pakan jauh lebih baik dari nila biasa. seperti ikan nila GIFT.

3. Rehabilitasi populasi ikan untuk meningkatkan produktivitasnya meliputi kegiatan introduksi atau penebaran ulang ikan nila, mas dan tawes: penetapan reservat perikanan, penetapan tata ruang perikanan dan pengendalian penangkap. an. Kegiatan tersebut perlu dirumuskan dalam bentuk pengelolaan perikanan dan ditetapkan dalam peraturan daerah (PERDA) setempat. 


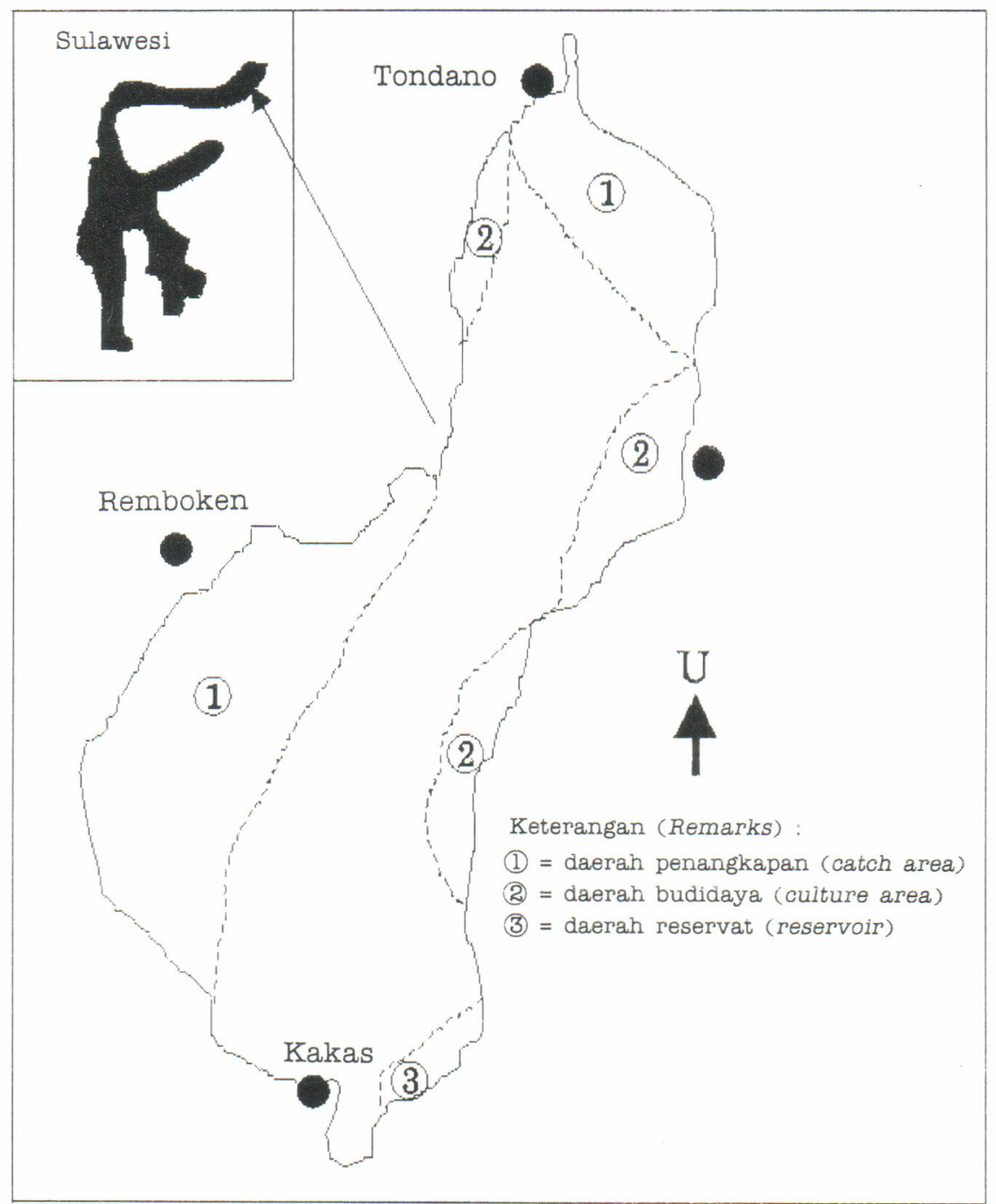

Gambar 4. Rencana tata ruang perikanan di I)anau Tondano.

Figure 4. Fisheries zoning plan for Lake Tondano.

\section{DAFTAR PUSTAKA}

Dinas Perikanan Kabupaten Minahasa. 1990. Laporan Dinas Perikanan Kabupaten Tk. II, Minahasa Tahun 1989/1990. Minahasa. Sulawesi Utara. 22 hal.

Dinas Perikanan Kabupaten Minahasa. 1996. Laporan Dinas Perikanan Kabupaten Tk. II, Minahasa Tahun 1994/1995. Minahasa. Sulawesi Utara. 31 hal.

Edmonson. W.T. 1959. Freshwater Biology. Second Edition. John Willey and Sons, Inc. 1248 pp.

Edmonson, W.T. and Winberg, G.G. 1971. A Manual on Methods for The Assessment on Secondary Productivity in Freshwaters. IBP Handbook No.17, Blackwell Sci. Pub. Oxford and Edinburgh. 1284 pp.

Efendie, M.I. 1979. Metode Biologi Perikanan. Yayasan Dewi Sri. Bogor. 112 hal.
Hall, E. 1971. Reservoir of fisheries and limnology. American Fisheries Society. Special Pub. No. 511 pp.

Hyslop, E.J. 1980. Stomach contents analysis-a review of methods and their applications. J. Fish. Biol. 17: 411.429 .

Nielson, L.A and Johnson, D.L. 1985. Fisheries Techniques. Am. Fish. Soc. Bethesda. Marryland. 468 pp.

Needham, J.G. and Needham, P.R. 1963. A Guide to the Study of Fre'shwater Biology. Holden-Day, Inc. San Francisco. 108 pp.

Nikolsky G.V. 1963. The Ecology of Fishes. Academic Press. New York. 325 pp.

Pianka,E.R. 1974. Evolutionary Ecology. Harper and Row Pub. New York, Evanston, San Francisco, London. $356 \mathrm{pp}$. 
Satria. H. 1997. Beberapa aspek biologi reprocluksi ikan payangka (Ophiorara pororephala) dan manggabai (Glussogobius giurus) di Perairan Danau Limboto. J. Penslit. Perilian. Indones. II(3): $72-79$.

Soeroto. B. 1988. Makanan dan Reproduksi than Ophieleotris apoxos (Bleeler) di Danau Tondano. Fakultas Pasca Sarjana IPB. Thesis. 187 hal.

Swales. S. and Ollara. K. 1983. A short-term study of the effects of habitat improvement programme on the distribution and abundance of lish stocks in Small Lowland River in Shropshire. Fish. Management. 14(3): 135-141
Umar. C. dan Krismono. 1996. Beberapa aspek bio. limnologi dan perikanan di Danau Tondamo. Sulawesi Utara. J. Prnelit. Periken. Indones. IV(1) $1-10$.

Whitten. A.J., Mustofa. M. and Henderson. (B.S. 1988. The Erology of Sulawesi. Gadjah Mada Universits Press. Yogvakata. p. 253-337.

Wotton. R.J 1989. Introduction: strategies and larcice in fish reproduction. In Potts. C.W.\& Walfon. R.J eds. Fish Reproduction: Strategirs and Tartics. Academic. Press. London. p. 1-12. 